\title{
Present State of Biota of Small Komi Republic Reservoirs
}

\author{
Maria A. Baturina*, \\ Olga N. Kononova, Elena B. Fefilova, \\ Boris Yu. Teteryuk, Elena N. Patova, \\ Angelina S. Stenina and Irina N. Sterlyagova \\ Institute of Biology, Komi Scientific Centre, UB RAS \\ 28 Kommunisticheskaya Str., Syktyvkar, 167982, Russia
}

Received 20.01.2017, received in revised form 16.04.2017, accepted 10.10.2017

Specific hydrological characteristics of small reservoirs and insufficiency of data on them determine the need for their integrate investigation to reveal the patterns of their ecosystems formation that could help to estimate their state in the future monitoring. The article presents the data on water chemistry and the main biological components (phyto - and zooplankton, zoobenthos, vascular plants, and mosses) of three small reservoirs situated in middle taiga subzone of Komi Republic. It was established that hydrochemical characteristics and flora and fauna species composition reflect regional specificity of the studied water bodies. Present stage of development of the reservoirs ecosystems was identified based on the analysis of the community structure. Characteristics of flora and fauna spatial distribution along the water body were studied. Ecological states of the investigated ecosystems were evaluated. Our results can be applied for prognosis of development of small river-type reservoirs.

Keywords: small reservoirs, subzone of middle taiga, algae, macrophytes, zooplankton, zoobenthos, water ecosystem development.

Citation: Baturina M.A., Kononova O.N., Fefilova E.B., Teteryuk B.Yu., Patova E.N., Stenina A.S., Sterlyagova I.N. Present state of biota of small Komi Republic reservoirs. J. Sib. Fed. Univ. Biol., 2017, 10(4), 422-445. DOI: 10.17516/1997-13890043.

(C) Siberian Federal University. All rights reserved

* Corresponding author E-mail address: baturina@ib.komisc.ru 


\title{
Современное состояние биоты малых водохранилищ Республики Коми
}

\author{
М.А. Батурина, О.Н. Кононова, \\ Е.Б. Фефилова, Б.Ю. Тетерюк,
} Е.Н. Патова, А.С. Стенина, И.Н. Стерлягова Институт биологии Коми НЦ УрО РАН Россия, 167982, Сыктывккар, ул. Коммунистическая, 28

\begin{abstract}
Гидрологические особенности малых водохранилищ и их недостаточная изученность определяют необходимость проведения комплексных исследований для выявления закономерностей формирования их экосистем с иелью оченки состояния при мониторинговых наблюдениях. В статье приводятся оригинальные данные по химическому составу вод и основным структурным показателям биологической компоненты (организмы фито- и зоопланктона, зообентоса, сосудистые растения и мохообразные) трех малых водохранилищ Республики Коми, расположенных в подзоне средней тайги. Выявлено, что гидрохимические условия и состав доминирующих видов флоры и фауны, основные сообщества выстих водных растений отражают региональную специфику исследованных гидроэкосистем. На основании анализа структурных показателей сообществ определен современный этап развития экосистемь каждого водоема. Отмечены особенности распределения флоры и фауны по их акватории. Дана оценка экологического состояния изученных водоемов. Результаты исследований могут быть использованы для прогноза развития мальх водохранилищ речного типа.
\end{abstract}

Ключевые слова: малые водохранилища, подзона средней тайги, водоросли, макрофиты, зоопланктон, зообентос, развитие водных экосистем.

\section{Введение}

Водохранилища - искусственно созданные экологические системы, по ряду параметров не имеющие аналогов в природе (Авакян и др., 1987). Они образуются на основе естественных водных объектов, но отличаются от них, прежде всего, целенаправленным регулированием стока (Кудерский, 1986). Поэтому для водохранилищ свойственны большая динамичность внутриводоемных процессов (Двинских, Китаев, 2014; Яныгина, 2016), меньшая устойчивость к антропогенному влиянию и неравномерность гидрологического режима из-за перестроек в процессе эксплуатации.
Таким образом, водохранилища представляют собой природно-техногенные комплексы (Малая гидроэнергетика, 1989; Двинских, Китаев, 2014), функционирование которых определяется, с одной стороны, природными условиями (сток, рельеф, климат, гидрохимический фон), с другой - техногенным воздействием (регулирование стока, наличие водозаборов или сбросов). В результате в водоемах формируются особые гидрологический (уровневый режим, расход воды, водообмен, проточность, течения, волнения) и гидрохимический (минерализация, главные ионы, биогенные вещества, микроэлементы, растворенные газы) режимы, которые в свою 
очередь и определяют специфичность развития экосистем водохранилищ и особенности формирования их биоты.

При создании крупных водохранилищ, как правило, организуют маршрутные мониторинговые наблюдения за формированием и функционированием их экосистем (Гольд и др., 1996; Куйбышевское водохранилище, 1983; Современное состояние..., 2002 и др.). Малые же водохранилища, несмотря на долгую историю их существования, вследствие незначительных размеров и меньшего хозяйственного значения остаются практически не изученными. Как правило, оценка их экологического состояния осуществляется для решения конкретной цели (Малая гидроэнергетика, 1989). Экосистемы этих водоемов отличаются не только размерами, но и отсутствием резких колебаний уровенного режима, относительно высокой долей мелководий и благоприятным режимом зарастания, что вероятно будет определять отличные от описанных ранее для других типов водохранилищ закономерности их формирования и функционирования. Для выявления особенностей процессов, происходящих в малых водоемах, необходимо на их акватории проводить регулярные комплексные исследования.

На территории Республики Коми в бассейнах малых рек было известно 18 искусственных водоемов разного генезиса (Биологическое обоснование..., 2012), созданных с различными целями (источники водоснабжения, в первую очередь для чугунно-литейного производства, источники энергии для привода турбин, мельниц, для регулирования уровня воды в реках при осуществлении молевого сплава и т.д.). Исследованные нами малые водохранилища: Нювчимское, Нючпасское, Кажимское, расположены в подзоне средней тайги в пределах бассейна одной реки. Все они были созданы в конце XVIII в. и имеют различную историю эксплуатации. Сейчас на двух из трех водоемов функционируют рыбоводные хозяйства.

Настоящая работа посвящена обобщению имеющихся сведений о гидрологическом, гидрохимическом режимах и составе биоты трех малых водохранилищ, расположенных в подзоне средней тайги Республики Коми, описанию динамики и особенностей формирования их экосистем, оценке современного состояния этих водоемов.

\section{Материалы и методы}

Полевые исследования Нювчимского, Нючпасского и Кажимского водохранилищ проводили с 2000 г. в разные годы (табл. 1), в основном в летние месяцы.

Изучение растительного покрова водохранилищ выполнено согласно методическим разработкам для гидроботанических исследований В.М. Катанской (1981). Всего собрано около 300 гербарных листов. Одновременно с выявлением состава флоры сосудистых растений были выполнены сборы мохообразных, собрано более 70 многовидовых пакетов ${ }^{1}$ В основу работы положено 226 полных геоботанических описаний. Методические подходы к сбору, обработке и интерпретации ботанического материала детально изложены в работах (Тетерюк, 2011, 2012).

Количественные пробы фито-, зоопланктона и зообентоса отбирали один раз в сезон, охватывая всю акваторию водоемов - от верхней «речной» части до приплотинной, включая заливы. Учитывая морфологические особенности водохранилищ, закладывали несколько гидробиологических разрезов. Кроме того, дополнительно в литорали водохранилищ отбирали интегральные пробы, вклю-

Определение мохообразных выполнено д.б.н. Г.В. Железновой (Институт биологии). 
Таблица 1. Сроки проведения полевых исследований

Table 1. Periods of field research

\begin{tabular}{|c|c|c|c|}
\hline \multirow{2}{*}{ Макрофиты } & \multicolumn{3}{|c|}{ Водохранилище } \\
\cline { 2 - 4 } & Нювчимское & Нючпасское & Кажимское \\
\hline \multirow{2}{*}{ Фитопланктон } & VIII.2014 & VIII.2016 & VIII.2008, VII.2013 \\
& VI.2011, IX.2012 (65) & данные отсутствуют & VII.2013, VIII.2014, VII.2015 \\
Зоопланктон & VII.2000, VII.2013/2014 & VIII.2007, VI.2011 & VII.2000, VIII.2007/2008, VII.2013, VIII.2014 \\
& $(23)$ & $(6)$ & $(27)$ \\
Зообентос & VII.2000, VII.2013/2014 & VIII.2007, VI.2011 & VII.2000, VIII.2007/2008, VII.2013 \\
& $(31)$ & $(8)$ & $(37)$ \\
\hline
\end{tabular}

Примечание: в скобках указано общее число проб.

чающие максимально возможное количество биотопов.

Для выявления разнообразия водорослей использовали пробы фитопланктона (50-100 л воды процеживали через планктонную сеть с размером ячеи 64 мкм), отбор проводили стандартным способом (Методика..., 1975; Руководство..,, 1983). Определение водорослей ${ }^{2}$ выполняли в лабораторных условиях в живых или зафиксированных 4\%-м формальдегидом или раствором Люголя пробах с помощью микроскопов МБИ-11 и NikonEclipse 80i. Определение диатомовых водорослей проводили после обработки проб кипячением с серной кислотой в постоянных препаратах. Уточнение номенклатурных изменений таксономического положения видов выполнено по AlgaeBase (Guiry, Guiry, 2016). В пробах фитопланктона осуществляли учет численности и биомассы водорослей методом прямого счета клеток с использованием камеры Горяева. Экологические характеристики видов приведены по (Krammer, Lange-Bertalot, 1991; Баринова и др., 2006; Ciblis Martina et al., 2013; Харитонов, 2014 и др.). Индексы сапробности воды рассчитаны по диатомовым

2 Диатомовые определяли только для Кажимского водохранилища. водорослям фитопланктона по Пантле-Буку в модификации Сладечека (Sládeček, 1973; Руководство..., 1983).

Зоопланктон отбирали по стандартной методике (Киселев, 1969): на глубоководных участках сетью Джеди, в прибрежье - посредством фильтрации 50-100 л воды через сеть Апштейна (размер ячеи 80 мкм). Камеральную обработку осуществляли в лабораторных условиях (Методика изучения..., 1975). Индивидуальный вес организмов зоопланктона рассчитывали по формулам (Балушкина, Винберг, 1979; Ejsmont-Karabin, 1998). Доминантные виды выделяли по относительной численности и биомассе, за нижнюю границу доминирования принимали обилие или биомассу $-5 \%$ от суммарных значений. Для полноты учета фауны все виды независимо от их экотопических характеристик (Протасов, $2011)$ относили к зоопланктону. Названия таксонов приведены в соответствии с принятыми в работе (Определитель..., 2010).

Отбор количественных проб зообентоса на мягких грунтах осуществляли дночерпателем Петерсена (с площадью захвата 1/40 м²). На небольших глубинах и на плотных грунтах применяли гидробиологический скребок (длина лезвия 0,3 м). Концентрировали пробы зообентоса, промывая их через капроно- 
вое сито с размером ячеи 230 мкм. Фиксацию проб проводили 4\%-м формальдегидом. В стационарных условиях животных выбирали под бинокуляром МБС-1. Массу донных беспозвоночных (кроме Cladocera и Copepoda) после обсушивания на фильтровальной бумаге определяли на торсионных весах WT-250 (Польша). Для характеристики структурных показателей развития зообентоса в исследованных водоемах рассчитывали численность, биомассу, частоту встречаемости для каждого таксона (Методика..., 1975).

Трофический статус водоемов оценивали по биомассе зообентоса и зоопланктона в соответствии с классификацией С.П. Китаева (2007).

Отбор проб воды и донных отложений для химического анализа выполняли параллельно с отбором гидробиологического материала. Измеряли температуру воды, $\mathrm{pH}$, концентрацию растворенного кислорода (портативным анализатором “Multi 340i/SET”, Германия). Прозрачность воды определяли с помощью диска Секки. Химико-аналитические работы были проведены в стационарных условиях по общепринятым методикам сотрудниками лаборатории «Экоаналит» Института биологии Коми НЦ УрО РАН (аттестат аккредитации № POCC RU.0001.511257 от 26 февраля 2014 г.).

\section{Результаты}

Условия среды и история функционирования исследованных водоемов

Изучаемые водоемы (Нювчимское, Нючпасское и Кажимское водохранилища) расположены в пределах бассейна реки Сысола (приток р. Вычегда) на юго-западе Республики Коми (рис. 1). По морфометрическим и гидрологическим признакам они относятся к проточно-русловым водоемам долинного типа, по размерным характеристикам - к категории «малых» (Авакян и др., 1987).

Нювчимское водохранилище, созданное в 1757 г. в месте слияния рек Нювчим и Дендель, было полностью спущено в конце 70-х гг. ХХ в., и залито вновь в 1998 г. после ремонта плотины и очистки ложа. Нючпасское построено в середине XVIII в. на слиянии рек Лопью и Нючпас. Это водохранилище каскадного типа, состоит из верхнего и нижнего прудов. Известно, что до 2007 г. действовал только нижний пруд, после восстановления плотины и проведения дноуглубительных работ на нижнем пруду в 2010 г. был залит и верхний пруд. Кажимское водохранилище существует с 1758 г. и внесено в «Кадастр особо охраняемых природных территорий Республики Коми» (2014) как водный памятник природы. В 2011-2012 гг. на нем была проведена реконструкция плотины, уровень воды был снижен, а в августе 2013 г. водохранилище было вновь поднято с затоплением прибрежной зоны.

Исследованные водоемы расположены в подзоне средней тайги. Эта территория характеризуется преобладанием торфянистоподзолисто-глеевых почв (Атлас почв..., 2010), в растительном покрове - еловых лесов. Речная сеть хорошо развита, густота ее составляет 0,62 км/км². Реки обеспечивают поверхностный приток вод во всех водоемах. Долины рек широкие, заболоченные. В целом заболоченность водосбора до $30 \%$, болота преимущественно водораздельные, верхового типа. Участие болотных вод в формировании химического состава воды способствует насыщению воды гумусовыми органическими веществами. В исследованных нами водохранилищах на это указывают показатели цветности воды, перманганатная и бихроматная окисляемость (табл. 2), значения которых не являются ано- 


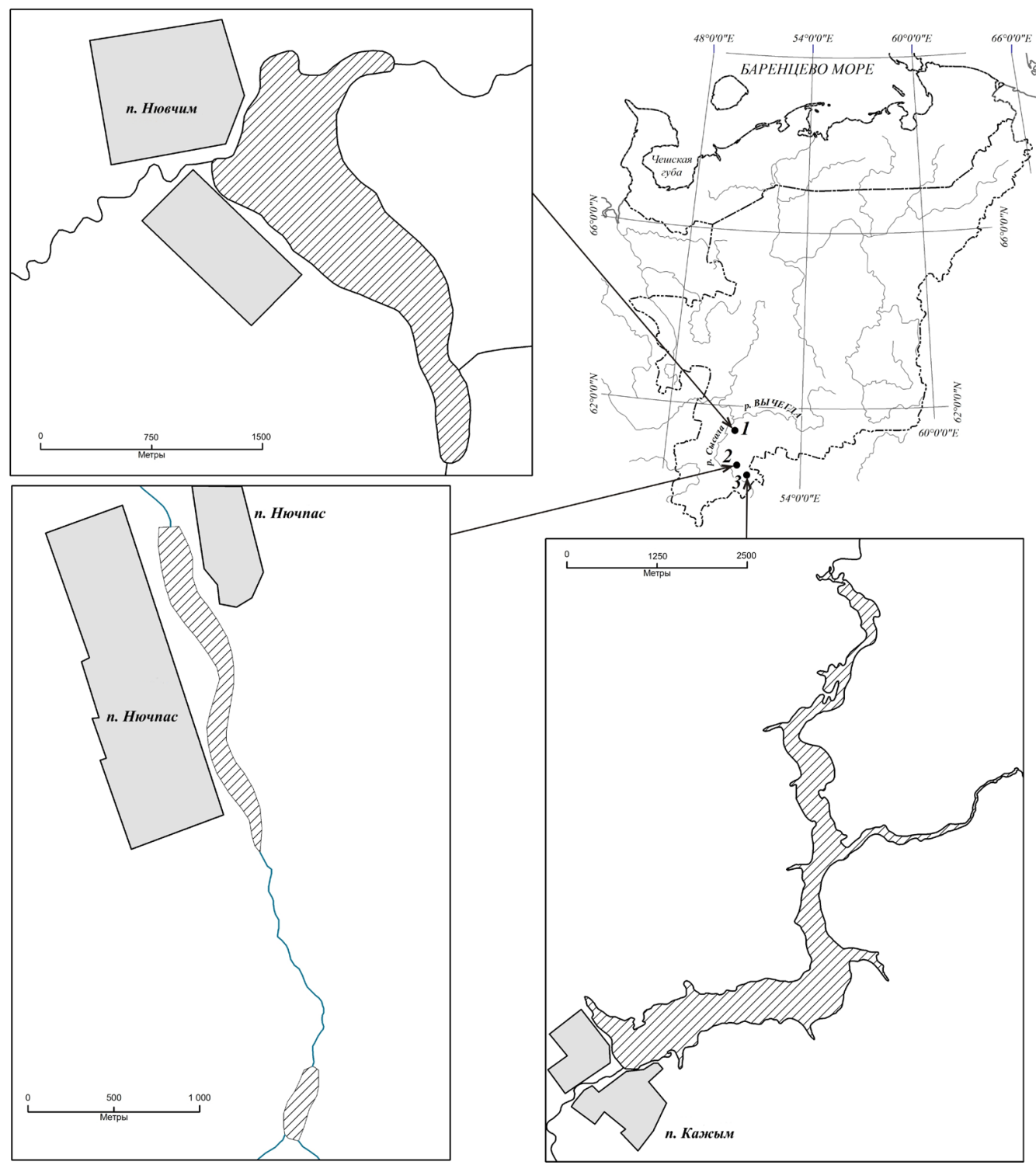

Рис. 1. Карта-схема местоположения исследованных водохранилищ: 1 - Нювчимское водохранилище; 2 - Нючпасское водохранилище; 3 - Кажимское водохранилище

Fig. 1. Map of the location of the reservoirs: 1 - The Nyvchim reservoir; 2 - The Nychpas reservoir; 3 - The Kazhim reservoir

мальными для поверхностных вод бассейна р. Сысола. Соответственно, вода в водохранилищах отличается высокой прозрачностью и низкой минерализацией (до 100 мг/ дм$^{3}$ ), по соотношению главных ионов относится к гидрокарбонатно-кальциевому типу. Активная реакция среды слабощелочная. Газовый состав вод в период исследований был благоприятным для развития гидробионтов. Водная вытяжка донных отложений характеризовалась кислым рН $(5,44-5,95)$ и повышенными концентрациями ионов кальция (101-610, максимально до 71000 мг/кг). Состав и концентрация прочих микроэлементов в донных отложениях находились в пределах характерных для региона (Атлас..., 
Таблица 2. Гидроморфологические и гидрохимические характеристики водохранилищ

Table 2. Hydromorphological and hydrochemical characteristics of the reservoirs

\begin{tabular}{|c|c|c|c|}
\hline & $\begin{array}{c}\text { Нювчимское } \\
\text { (2013 г.) }\end{array}$ & $\begin{array}{l}\text { Нючпасское } \\
\text { (2011г.) }\end{array}$ & $\begin{array}{c}\text { Кажимское } \\
\text { (2013 г. } \\
\text { до подъема уровня) }\end{array}$ \\
\hline Координаты & $\begin{array}{l}N^{\circ} 61,405 \\
E^{\circ} 50,773\end{array}$ & $\begin{array}{l}N^{\circ} 60,682 \\
E^{\circ} 51,481\end{array}$ & $\begin{array}{l}\mathrm{N}^{\circ} 60,361 \\
\mathrm{E}^{\circ} 51,621\end{array}$ \\
\hline \multicolumn{4}{|c|}{ гидроморфологические параметры } \\
\hline Генезис & речное & речное & речное \\
\hline Площадь, га & 172,0 & 7,0 & 144,7 \\
\hline Ширина, км & 0,5 & 0,15 & 0,5 \\
\hline Длина, км & 3,4 & 0,9 & 4,5 \\
\hline Глубина, м (макс/ср) & $6,3 / 2,3$ & $5 / 2,5$ & $8,8 / 3,6$ \\
\hline Преобладающий грунт & песок, глина & $\begin{array}{c}\text { песок, ил } \\
\text { детрит }\end{array}$ & песок, ил \\
\hline Проточность & + & + & + \\
\hline \multicolumn{4}{|c|}{ гидрохимические параметры, min - max (средняя) } \\
\hline Температура воды, ${ }^{\circ} \mathrm{C}$ & $\begin{array}{c}22,7-23,4 \\
(23,4)\end{array}$ & нет данных & $\begin{array}{c}22,3-24,7 \\
(23,2)\end{array}$ \\
\hline Прозрачность, м & $\begin{array}{l}0,3-2,0 \\
\quad(1,4)\end{array}$ & нет данных & $\begin{array}{l}0,5-0,8 \\
\quad(0,7)\end{array}$ \\
\hline $\mathrm{O}_{2}, \%$ & $76,0-100,0$ & $79,0-92,0$ & $65,0-89,7$ \\
\hline Цветность, град & $54,3-82,3$ & $182,0-216,0$ & $153,0-183,0$ \\
\hline 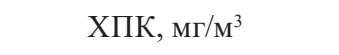 & $26,0-35,0$ & $41,0-47,0$ & $35,0-40,0$ \\
\hline ПО, мгО $\mathrm{O}_{2} / \mathrm{M}^{3}$ & $9,0-10,0$ & $14,9-18,3$ & $18,4-19,2$ \\
\hline $\mathrm{pH}$ & $7,4-8,9$ & $7,1-7,2$ & $6,5-7,1$ \\
\hline Минерализация, мг/дм³ & $\max 102,4$ & $\max 44,8$ & $\max 45,4$ \\
\hline $\mathrm{Ca}^{2+}$, мг/дм ${ }^{3}$ & $13,1-18,6$ & $7,9-8,6$ & $4,8-5,7$ \\
\hline $\mathrm{Mg}^{2+}, \mathrm{мг} / д \mathrm{M}^{3}$ & $2,9-3,2$ & $1,5-1,5$ & $1,3-1,5$ \\
\hline $\mathrm{Na}^{+}$, мг/дм ${ }^{3}$ & $3,0-3,3$ & $2,2-2,3$ & $2,2-2,6$ \\
\hline $\mathrm{K}^{+}$, мг/дм ${ }^{3}$ & $0,38-0,42$ & $0,44-0,61$ & $0,30-0,42$ \\
\hline $\mathrm{P}_{\text {общ }}, \mathrm{Mг} / \mathrm{дM}^{3}$ & $<0,03-0,04$ & $0,04-0,11$ & $0,06-0,07$ \\
\hline $\mathrm{N}_{\text {общ, }}$ мГ/дм ${ }^{3}$ & $0,36-0,42$ & нет данных & $0,37-0,47$ \\
\hline $\mathrm{Fe}$, мг/дм ${ }^{3}$ & $0,04-0,30$ & $0,32-0,38$ & $0,89-1,24$ \\
\hline $\mathrm{Cu}, \mathrm{мг} / д \mathrm{M}^{3}$ & $<1,0$ & $0,5-0,9$ & $1,5-2,4$ \\
\hline
\end{tabular}

2010). Сопоставление химического состава грунтов показало, что содержание $\mathrm{N}_{\text {общ}}, \mathrm{C}_{\text {общ, }}$ органического вещества в зонах расположения рыбоводных садков в 1,1-1,2 раза выше, чем на отдаленных участках.

Проведенные в 2011-2012 гг. ремонтные работы на плотине Кажимского водохранилища привели к подтоплению берегов, в том числе и оторфованных участков с развитой на них растительностью, и к частичному заболачиванию. В результате к 2014 г. наблюдалось увеличение значений цветности воды (превышение ПДК минерализации воды в 2,8 раза, концентрации растворенных веществ - в 2,2 раза, значений БПК 5 (превышение ПДК 
и ХПК (превышение ПДК рбхз в 1,8 раза). При этом отмечались изменения концентрации основных биогенных элементов (общий азот и фосфор), хотя их значения находились в пределах ПДК $\mathrm{P}_{\text {общ. }}-0,020-0,039 \mathrm{мг} /$ дм $\left.^{3}\right)$.

Согласно классификации водоемов (ГОСТ 17.1.2.04-77) по большинству химических параметров Нювчимское водохранилище оценивалось как олигосапробный водоем, Нючпасское и Кажимское - как $\beta$-мезосапробные.

Bce водохранилища характеризуются проточностью, волнистым рельефом дна. Дно водоемов сложено песчаными и глинистыми грунтами, часто заиленными или покрытыми детритом. Наиболее глубокие участки (табл. 2) расположены непосредственно у плотин и вдоль старых русел рек.

Нювчимское и Кажимское водохранилища с 2007 г. используются в целях товарного разведения форели рода Salmo и карпа (Cyprinus carpio Linnaeus, 1758). Садковые площади хозяйств составляют не более $1 \%$ площади водохранилищ, где в сумме выращивали на период исследований около 300 т рыбы в год.
Водоросли

В состав альгофлоры исследованных водохранилищ входят водоросли из восьми отделов (табл. 3). Наиболее разнообразен состав диатомовых (на примере Кажимского водохранилища), а именно семейств Fragilariaceae (29 видов с разновидностями и формами), Naviculaceae (28), Eunotiaceae (22), Pinnulariaceae (21), Achnanthidiaceae (18), Bacillariaceae, Cymbellaceae (по 16) и Gomphonemataceae (13 таксонов). Чаще всего в пробах фитопланктона отмечены представители родов Aulacoseira, Epithemia, Pseudostaurosira, Staurosira и Staurosirella, характерных как для олиготрофных, так и мезо- и эвтрофных водоемов. На втором месте по разнообразию стоят зеленые водоросли (табл. 3), в обоих водоемах преобладают семейства Desmidiaceae (16 видов) и Chlorococcaceae (9) и роды Cosmarium, Closterium, Staurastrum, Scenedesmus. На третьем месте - цианопрокариоты, ведущие семейства Nostocaceae (9), Phormidiaceae (8), Pseudanabaenaceae (6) и роды Nostoc, Anabaena, Dolichospermum. Видовое богатство остальных отделов невысоко.

В период исследований в Нювчимском и Кажимском водохранилищах отмечалось

Таблица 3. Состав альгокомплексов исследованных водохранилищ

Table 3. Composition of algal community of the studied reservoirs

\begin{tabular}{|c|c|c|}
\hline \multirow{2}{*}{ Отдел } & Нювчимское водохранилище & Кажимское водохранилище \\
\cline { 2 - 3 } & \multicolumn{2}{|c|}{ число видов/родов/семейств } \\
\hline Cyanoprokaryota & $24 / 10 / 5$ & $28 / 12 / 7$ \\
Rhodophyta & $1 / 1 / 1$ & $1 / 1 / 1$ \\
Chrysophyta & $2 / 1 / 1$ & $1 / 1 / 1$ \\
Bacillariophyta & не исследованы & $220 / 57 / 24$ \\
Xanthophyta & $4 / 2 / 2$ & $2 / 1 / 1$ \\
Euglenophyta & $2 / 2 / 1$ & $2 / 1 / 1$ \\
Raphidophyta & не обнаружены & $1 / 1 / 1$ \\
Chlorophyta & $39 / 17 / 9$ & $42 / 18 / 9$ \\
Bсего & $72 / 33 / 19$ & $297 / 92 / 45$ \\
\hline
\end{tabular}


«цветение» воды. Комплекс видов, вызывающих это явление, был сходен в обоих водоемах. Основу фитопланктона формировали $\beta$ и олиго- $\beta$-мезосапробные виды синезеленых водорослей - Aphanizomenon flosaquae Ralfs ex Born. \& Flah., Dolichospermum flosaquae (Bréb. ex Born. \& Flah.) P. Wacklin, L. Hoffmann \& J. Komárek и Anabaena planctonica Brunnthaler, диатомовых - Aulacoseira italica (Kütz.) Sim., $\beta$-мезосапробные и олиго- $\alpha$-мезосапробные виды зеленых - Monoraphidium contortum (Thur.) Komárková-Legnerová и Crucigenia tetrapedia (Kirch.) Kuntze, колониальная водоросль Pediastrum boryanum (Turp.) Menegh., а также представители десмидиевых водорослей из рода Closterium. Отличительной особенностью Кажимского водохранилища являлось массовое развитие в фитопланктоне желтозеленой водоросли Tribonema subtilissimum Pascher, обитателя заболоченных водоемов, а также здесь впервые для Республики Коми было отмечено развитие высокоэвтрофного инвазийного токсичного вида рафидофитовой водоросли Gonyostomum semen (Ehr.) Diesing.

В Нювчимском водохранилище в 2011 г. общая численность водорослей на станциях колебалась от 780 до 3500 тыс. клеток/л при биомассе от 0,60 до 0,98 мг/л, что по пятибалльной шкале О.П. Оксиюк, Ф.В. Стольберг (1986) соответствует первой стадии «цветения» водоемов. В 2012 г. эти показатели заметно снизились и составляли соответственно 230-500 тыс. клеток/л численность и от 0,24 до 0,67 мг/л биомасса водорослей. По количественным показателям развития превалировали диатомовые водоросли, при этом максимальные показатели развития фитопланктона были зафиксированы на участках вблизи садков.

Интенсивное развитие водорослей, достигающее стадии «цветения» (по шкале О.П.
Оксиюк, Ф.В. Стольберг, 1986) отмечалось и в Кажимском водохранилище в 2014-2015 гг. (второй и третий годы после ремонта плотины и подъема уровня воды). Вода по всей акватории была окрашена в зеленый цвет, общая численность водорослей изменялась в пределах 814-5486 тыс. клеток/л при биомассе 0,450,88 мг/л в 2014 г. и 814-950 тыс. клеток/л при биомассе до 0,45 мг/л в 2015 г. При этом вода у берегов и в середине ближнего залива относилась к категории «чистая» (II класс), в зоне садков - «умеренно загрязненная» (III класс): индексы сапробности изменялись в пределах 1,44-1,57. Наиболее загрязненная станция находилась непосредственно у садков, где вода оценивалась как «очень сильно загрязненная» ( $\mathrm{V}$ класс): индекс сапробности составлял 3,57. Соотношение групп диатомей - индикаторов трофического статуса водоема (рис. 2) показало, что разница между индикаторами олиготрофных (30\%), мезотрофных условий (25\%) и толерантными видами (34 \%) была небольшая.

В целом, на основе таксономической структуры водорослей, состава ведущих видов, основных экологических группировок и индексов сапробности (Оксиюк и др., 1993) Кажимское и Нювчимское водохранилища в период исследований характеризовались как олиготрофно-мезотрофные водоемы.

\section{Макрофить}

$$
\text { Флора исследованных водохрани- }
$$
лищ включает 119 видов высших растений (табл. 4). Ведущее положение по числу видов в растительном покрове принадлежит семействам Cyperaceae (10,5-13,9 \%), Potamogetonaceae (6,3-11,6 \%), Polygonaceae (7,9-11,6 \%), Poaceae (6,6-8,9 \%). Доля мохообразных 9-13\%. Наибольшее распространение в Нювчимском водохранилище имеют Elodea canadensis Michx., Persicaria amphibia 


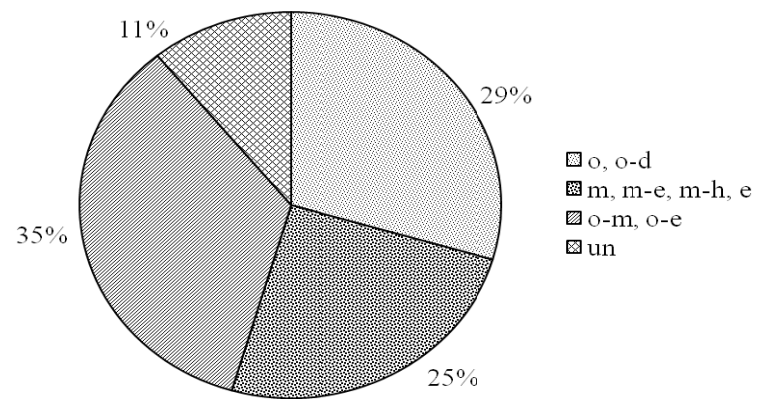

Рис. 2. Соотношение групп видов - индикаторов уровня трофности в диатомовом комплексе Кажимского водохранилища. Группы: o, o-d - олиготрофная, олиготрофно-дистрофная; o-e, o-m - олиготрофноэвтрофная, олиготрофно-мезотрофная; m-e, e, m-h - мезотрофно-эвтрофная, эвтрофная, мезотрофногиперэвтрофная, un - характеристика неизвестна

Fig. 2. Percentage distribution of groups of the trophic state indicator species in diatom complex of the Kazhim reservoir: o, o-d - oligotrophic, oligotrophic-distrophic; o-e - oligotrophic-eutrophic, o-m - oligotrophicmesotrophic, m-e, e, m-h - mesotrophic-eutrophic, eutrophic, mesotrophic-hypereutrophic, un - characteristic is unknown

Таблица 4. Систематическая структура флоры водохранилищ

Table 4. The systematic structure of reservoirs flora

\begin{tabular}{|l|c|c|c|}
\hline \multirow{2}{*}{\multicolumn{1}{|c|}{ Основные показатели }} & \multicolumn{3}{|c|}{ Водохранилище } \\
\cline { 2 - 4 } & Кажимское & Нювчимское & Нючпасское \\
\hline Общее число видов & 79 & 76 & 33 \\
Общее число родов & 49 & 48 & 24 \\
Общее число семейств & 33 & 35 & 66,7 \\
Доля одновидовых семейств, \% & 42,4 & 57,1 & 6 \\
Макс. число видов в одном семействе & 9 & 8 & 8,7 \\
Доля мхов, \% & 12,7 & 9,2 & 67,4 \\
Доля видов в 10 ведущих & 58,2 & 60,5 & \\
семействах, \% & & & \\
\hline
\end{tabular}

(L.) S.F. Gray, Lemna trisulca L., Potamogeton natans L., Potamogeton perfoliatus L., Callitriche hermaphroditica L. В Нючпасском - Carex rostrata Stokes, $P$. natans, $P$. perfoliatus, Callitriche palustris L., Typha latifolia L. B Kaжимском - P. natans, $P$. perfoliatus, Carex aquatilis Wahlenb, C. rostrata, Sparganium emersum Rehm., Callitriche palustris L.

Степень зарастания Нювчимского водохранилища составляла около $40 \%$. В воде и на берегах были отмечены сообщества 18 ассоциаций. На сырых и заболоченных берегах водохранилища были сформированы ценозы ассоциаций Equiseto fluviatilisCaricetum rostratae Rübel 1912, Caricetum aquatilis Savič 1926, Equisetetum fluviatilis Nowiński 1930. На левом берегу средней части водохранилища отмечены мелкоконтурные заросли рогоза широколистного Typhetum latifoliae Nowiński 1930. Повсеместно в водных местообитаниях верхней и средней частей водохранилища распространены сообщества Elodeetum canadensis Nedelcu 1967 и реже Potametum perfoliati 
Miljan 1933, перемежающиеся в затишных прибрежных участках с сообществами Lemnetum trisulcae den Hartog 1963. На прибрежных мелководьях были обычны ценозы ассоциации Sparganietum emersi Mirkin, Gogoleva et Kononov 1985.

Степень зарастания двух разновозрастных прудов Нючпасского водохранилища составляла 10-12 \%. Его растительный покров формировали сообщества 12 ассоциаций. На мелководьях верхнего пруда распространены заросли рдеста плавающего (Potametum natantis Hild 1959) и кочующие торфяные сплавины с рогозом широколистным (Typhetum latifoliae), на нижнем пруду наиболее крупные заросли макрофитов приурочены к нижней (приплотинной) части и сформированы они рдестом плавающим (Potametum natantis) и красовлаской болотной (Lemno-Callitrichetum palusrtis A. Bobrov et Chemeris 2006).

Кажимское водохранилище имело зарастание в 10-12\%. Растительный покров водохранилища формировали сообщества 13 ассоциаций. Сплошные заросли рдеста пронзённолистного (Potametum perfoliati), чередующиеся с сообществами кубышки жёлтой (Potamo-Nupharetum luteae Müller et Görs 1960), формируются преимущественно в его верхней мелководной части. На обсыхающих мелководьях и сырых берегах обычны заросли гигрофильных осок (Caricetum aquatilis, Equiseto fluviatilis-Caricetum rostratae), сменяющиеся в нижней (приплотинной) части на вытаптываемых песчаных местообитаниях сообществами ассоциации Ranunculo repentisAgrostitetum stoloniferae Oberdorfer et al. 1967. В верхней части на заболоченных берегах были отмечены мелкоконтурные сообщества Typhetum latifolia. Значительно меньших размеров (до $3 \mathrm{~m}^{2}$ ) рогозовое сообщество встречается на песчаной отмели в приплотинной части.

\section{Зоопланктон}

Всего в составе зоопланктона исследованных водохранилищ выявлено 110 видов и форм (в Нювчимском - 65; Нючпасском - 32; Кажимском - 90). Во всех водоемах наиболее разнообразно представлены коловратки (Rotatoria) и ветвистоусые раки (Cladocera).

В Нювчимском водохранилище в первые годы после его восстановления в зоопланктоне как по численности, так и по биомассе доминировали коловратки (табл. 5) - представители родов Synchaeta, Polyarthra и Asplanchna priodonta Gosse. Многочисленными были науплиусы и копеподиты веслоногих раков. На современном этапе его становления большую роль в планктонном сообществе приобрели низшие раки (табл. 5), образующие в прибрежье, среди зарослей водных макрофитов, до 95 \% биомассы зоопланктона.

В Нючпасском водохранилище до ремонта плотины в нижнем пруду количественные показатели развития зоопланктона были невысокими (рис. 3). Превалировали в планктоне коловратки, биомассу наряду с ними образовывали ветвистоусые раки Ceriodaphnia pulchella Sars, Daphnia longispina O.F. Müller и рода Bosmina. После ремонта плотины и наполнения верхнего пруда в 2010 г. численность и биомасса зоопланктона в нижнем значительно уменьшились (рис. 3). В водоеме стали доминировать коловратка $A$. priodonta и ветвистоусый рачок Polyphemus pediculus L. (табл. 5). Многочисленными были неполовозрелые формы Cyclopoida. B то же время в верхнем пруду в 2011 г. (первый год после восстановления) низкие количественные показатели развития зоопланктона были обусловлены массовым развитием коловраток Lophocharis naias Wulfert, Bdelloida и неполовозрелых форм веслоногих раков; биомассу в нем формировали немногочис- 


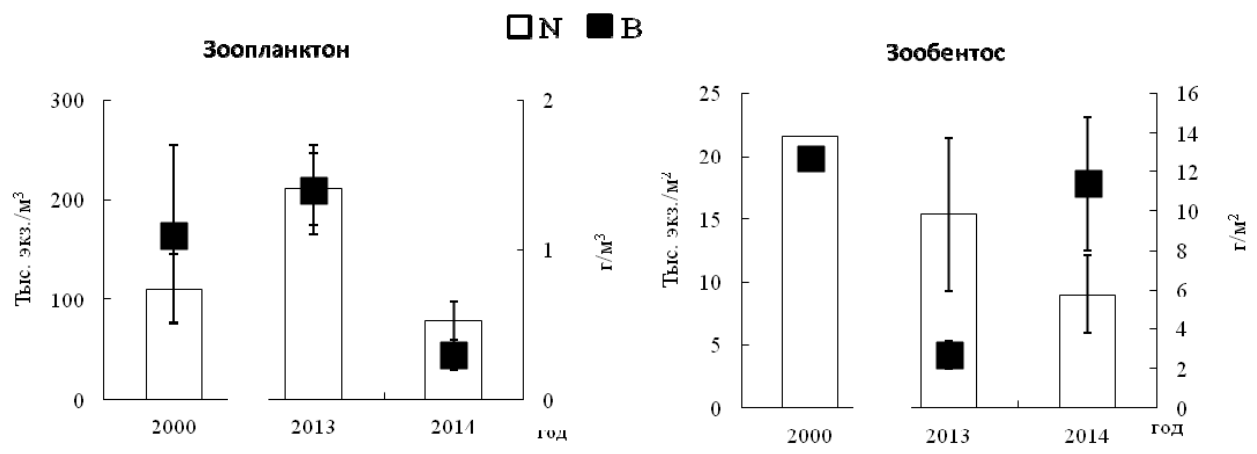

Нювчимское водохранилище
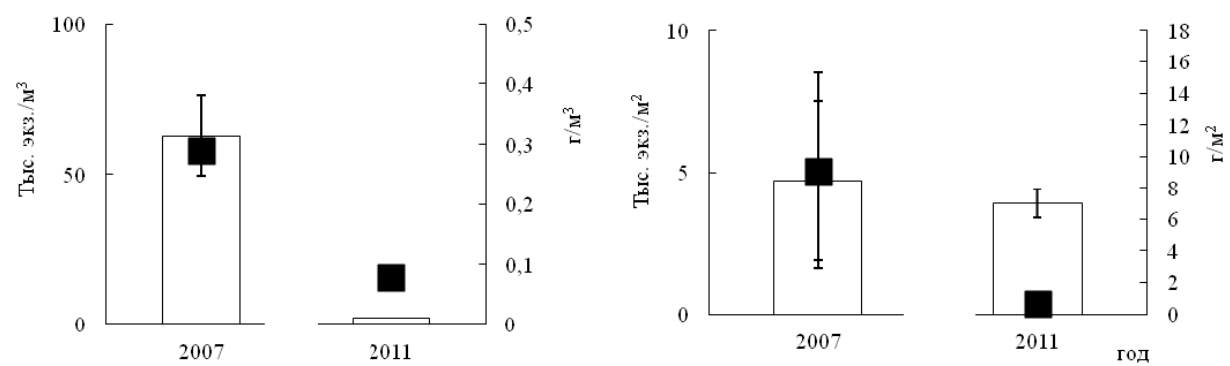

Нючпасское водохранилище (нижний пруд)
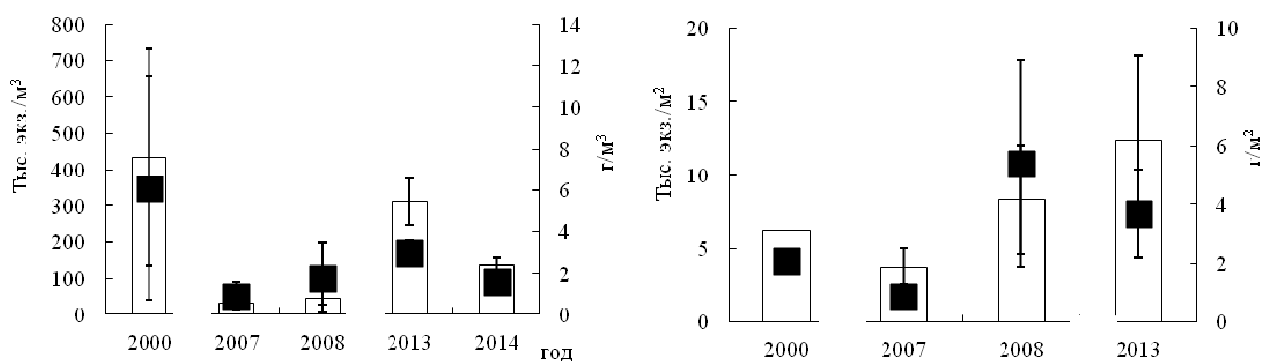

Кажимское водохранилище

Рис. 3. Численность (N) и биомасса (B) зоопланктона и зообентоса в исследованных водохранилищах. На диаграммах указана ошибка средней

Fig. 3. The abundance $(\mathrm{N})$ and biomass (B) of zooplankton and zoobenthos (means \pm SE) in the studied reservoirs

ленные представители веслоногих раков рода Eucyclops и Macrocyclops albidus (Jurine), а также науплии и копеподиты Cyclopoida. B прибрежье численность и биомассу наряду с коловратками образовывали ветвистоусые раки Scapholeberis mucronata (O.F. Müller) и P. pediculus.

В Кажимском водохранилище в первый год наблюдений (2000 г.) высокую численность зоопланктона (рис. 3) обеспечивали эвпланктонные коловратки - Conochilus unicornis Rousselet, Keratella cochlearis (Gosse), виды родов Polyarthra и Synchaeta. Биомассу, напротив, составляли ветвистоусые раки преимущественно родов Bosmina, Daphnia, Ceriodaphnia (в сумме до 93 \%). В 2007-2008 гг. наблюдали спад в развитии планктонных организмов. После реконструкции плотины (по данным за 2013-2014 гг.) обилие зоопланктона в водохранилище вновь возросло (рис. 3). В сообществе доминировали как ветвистоусые раки (максимально до 88 \% обилия 


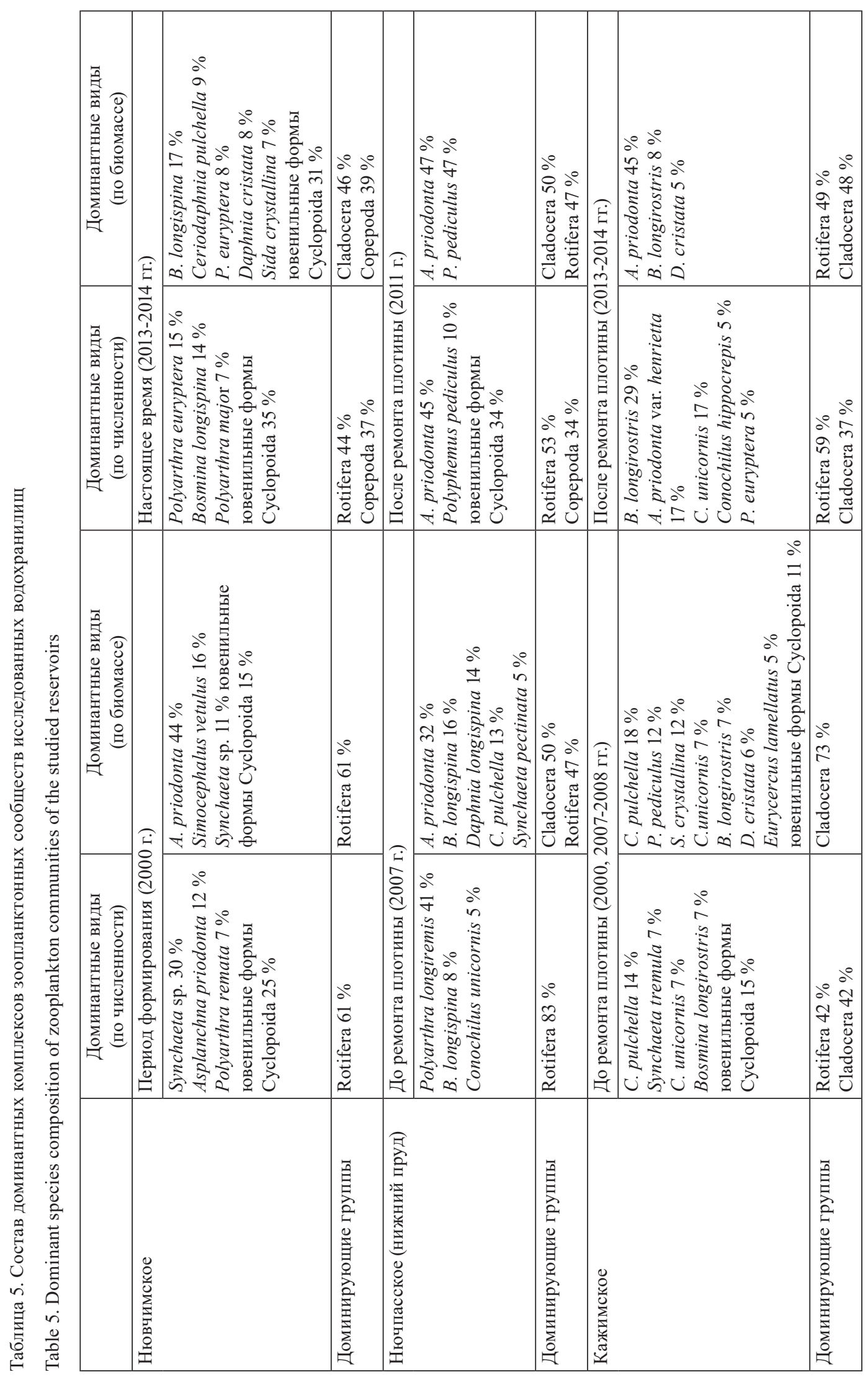


и $95 \%$ общей биомассы), так и коловратки (максимально до 95 \% общей численности и 96 \% биомассы) (табл. 5).

На примере Нювчимского (настоящее время) и Кажимского (до реконструкции) водохранилищ была выявлена тенденция к увеличению численности планктонных организмов от верхней речной к приплотинной части (табл. 6). При этом в Нювчимском по численности доминировали коловратки: Polyarthra euryptera Wierzejski и Synchaeta tremula (Müller) и ювенильные Cyclopoida, а в Кажимском - ветвистоусые раки: Sida crystallina (O.F. Müller), P. pediculus, C. pulchella, Daphnia (D.) cristata G.O. Sars и представители рода Bosmina. Биомасса планктона в Нювчимском водохранилище, напротив, была выше на участке со стороны впадения р. Нювчим (табл. 6), что, вероятно, обусловлено развитием здесь высших водных растений и, как следствие, массовым развитием фитофильных видов, а в зоне открытой воды - Limnosida frontosa Sars и Mesocyclops leuckarti (Claus).

По уровню развития биомассы зоопланктона Нювчимское водохранилище характеризовалось как олиготрофный, Кажим- ское - как $\alpha$-мезотрофный, Нючпасское - как ультраолиготрофный водоем (Китаев, 2007).

\section{Зообентос}

В составе зообентоса водохранилищ установлено 22 систематические группы донных беспозвоночных (18 - в Нювчимском; 10 - в Нючпасском и 21 - в Кажимском водохранилище). Всегда в пробах бентоса присутствовали низшие ракообразные (Cladocera, Cyclopoida, Ostracoda), черви (Nematoda, Oligochaeta), моллюски (Mollusca), личинки комаров-звонцов (Chironomidae) и часто поденок (Ephemeroptera).

В Нювчимском водохранилище (рис. 3) наибольшая численность бентоса отмечалась в 2000 г. на третий год после восстановления плотины, при этом основную роль в формировании численности играли мейобентические низшие ракообразные Ostracoda, Cladocera и личинки Chironomidae в составе макробентоса (рис. 4). Высокие значения биомассы донных беспозвоночных в этот период определялись за счет массы Mollusca и личинок Chironomidae. В 2013-2014 гг., к 16-му году эксплуатации общие количественные показатели развития бентоса снизились (рис. 3).

Таблица 6. Средние показатели численности $(\mathrm{N} \pm \mathrm{m})$ и биомассы $(\mathrm{B} \pm \mathrm{m})$ зоопланктона и зообентоса в Нювчимском и Кажимском водохранилищах на различных участках акватории

Table 6. The average abundance $(\mathrm{N} \pm \mathrm{m})$ and biomass $(\mathrm{B} \pm \mathrm{m})$ of zooplankton and zoobenthos in different parts of water areas of the Nyvchim and Kazhim reservoirs

\begin{tabular}{|c|c|c|c|c|}
\hline \multirow{2}{*}{ Группа } & \multicolumn{2}{c|}{ Нювчимское вдхр. } & $\mathrm{N}$ & $\mathrm{B}$ \\
\cline { 2 - 5 } & $\mathrm{N}$ & $\mathrm{B}$ & $29,6 \pm 9,3$ & $0,39 \pm 0,02$ \\
\hline \multicolumn{5}{|c|}{ Верхний участок, приречной } \\
\hline Зоопланктон & $147,3 \pm 40,7$ & $1,30 \pm 0,50$ & $12,5 \pm 8,5$ & $2,60 \pm 2,30$ \\
Зообентос & $17,4 \pm 7,0$ & $4,50 \pm 1,70$ & $41,6 \pm 14,4$ & $1,68 \pm 1,02$ \\
\hline \multicolumn{5}{|c|}{ Нижний участок, приплотинный } \\
\hline Зоопланктон & $182,1 \pm 41,8$ & $0,85 \pm 0,25$ & $3,8 \pm 2,1$ & $2,60 \pm 0,80$ \\
Зообентос & $8,2 \pm 6,2$ & $4,80 \pm 2,60$ & 25 в \\
\hline
\end{tabular}

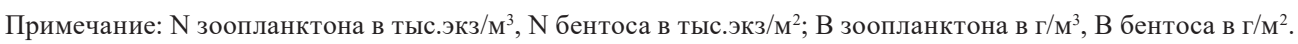




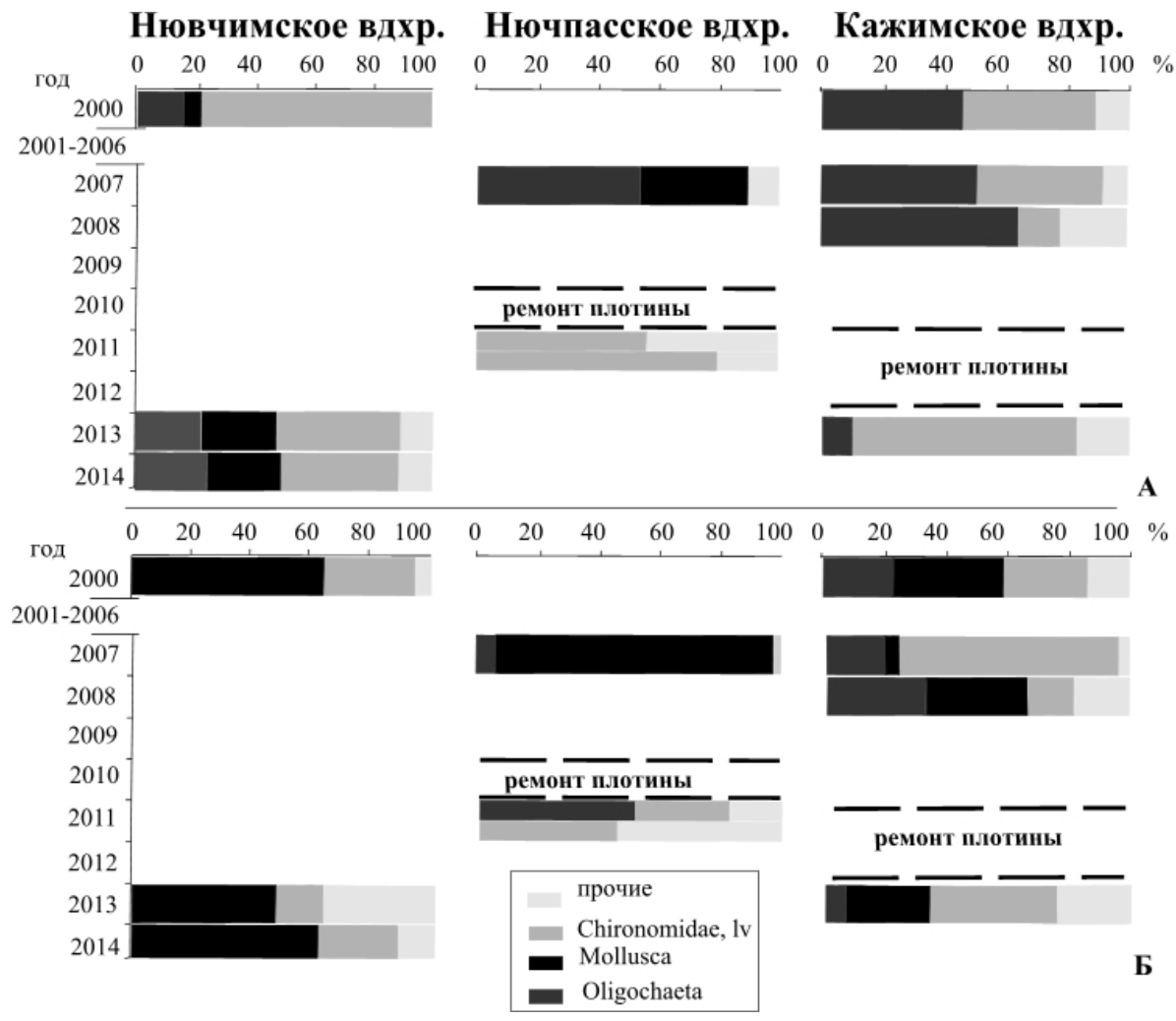

Рис. 4. Доля (\%) от общей численности (А) и биомассы (Б) доминирующих групп макрозообентоса в водохранилищах в разные годы исследований. К группе «прочие» относятся: Hydrazoa, Nematoda, Hirudinea, Tardigrada, Cladocera, Cyclopoida, Harpacticoida, Ostracoda, Hydracarina, Collembola, Odonata, Ephemeroptera, Hemiptera, Coleoptera, Megaloptera, Trichoptera, Simuliidae, Ceratopogonidae, прочие Diptera

Fig. 4. Percentage of total abundance (A) and biomass (B) of the dominant groups of macrozoobenthos in the reservoirs in different years. "Others" include: Hydrazoa, Nematoda, Hirudinea, Tardigrada, Cladocera, Cyclopoida, Harpacticoida, Ostracoda, Hydracarina, Collembola, Odonata, Ephemeroptera, Hemiptera, Coleoptera, Megaloptera, Trichoptera, Simuliidae, Ceratopogonidae, other Diptera (except Chironomidae, Simuliidae, Ceratopogonidae)

В водохранилище по-прежнему отмечалась высокая доля бентосных рачков (в сумме более $70 \%$ общей численности). В макробентосе по численности преобладали личинки хирономид (27\%), малощетинковые черви и моллюски. Основу биомассы (47,6%) бентоса составляли преимущественно моллюски (рис. 4).

В нижнем пруду Нючпасского водохранилища до ремонта плотины (по данным 2007 г.) было сформировано зарастающее водными макрофитами прибрежье. Здесь от- мечался разнообразный состав групп и относительно высокие значения численности и биомассы бентосных животных (рис. 3). Численность бентоса в прибрежье формировали Oligochaeta и Mollusca, личинки Chironomidae и Cyclopoida. Биомасса бентоса на 89 \% определялась моллюсками (рис. 4). После реконструкции плотины и образования верхнего пруда (2011 г.) численность зообентоса в нижнем снизилась в 1,2 раза, а биомасса - в 12 раз (рис. 3). По численности доминировали преимущественно личинки Chironomidae, в био- 
массе лидирующие позиции заняли малощетинковые черви (47\%) и личинки хирономид (27 \%). Количественные показатели развития зообентоса в верхнем пруду в 2011 г., в первый год существования, были выше, чем в нижнем - численность в 1,7, биомасса в 2,9 раза за счет развития личинок Chironomidae и прочих групп гетеротопных насекомых: Ephemeroptera, Megaloptera, которые в сумме составляли 83,5 \% общей биомассы бентоса, повторяя структуру макрофауны р. Лопью, в ложе которой и было сформировано водохранилище.

В Кажимском водохранилище средняя численность зообентоса на первом этапе наблюдений (2000 г.) и в 2007-2008 гг. была ниже по сравнению с периодом после восстановления плотины и подъема уровня воды (рис. 3), при близких значениях биомассы. В первые годы (2000, 2007-2008 гг., рис. 4), основную роль в бентосе играли личинки Chironomidae, Oligochaeta, доминирующие по биомассе и численности и Mollusca, доминирующие по биомассе. После ремонта плотины, спуска и последующего подъема уровня воды, по данным за 2013 г., в общей численности бентоса преобладали в основном личинки хирономид, по биомассе - личинки хирономид и моллюски.

В распределении зообентоса по акватории водоемов были также выявлены общие черты. Наибольшие показатели численности и разнообразный состав бентоса отмечался в верхних речных участках водохранилищ (табл. 6). Такое распределение наблюдали в Нювчимском водохранилище, где в верхней части встречено 9-11 таксономических групп и численность бентоса была выше в два раза по сравнению с нижним приплотинным участком, где указывалось только 7-9 групп беспозвоночных. В Кажимском также установлены различия на этих участках и до и после реконструкции плотины, но в 2013 г. высокие показатели количественного развития определялись обилием в нем личинок Chironomidae.

По уровню развития биомассы зообентоса Нювчимское водохранилище характеризовалось как $\beta$-мезотрофный, Кажимское - как $\alpha$-мезотрофный, Нючпасское - как олиготрофный водоем в соответствии с классификацией С.П. Китаева (2007).

\section{Обсуждение}

Химический состав вод исследованных водохранилищ в целом соответствовал его региональным особенностям в водоемах среднетаежной подзоны на территории Республики Коми (Власова, 1988; Атлас почв..., 2010). Подтопление берегов и оторфованных участков с развитой на них растительностью после подъема уровня воды, связанного с реконструкцией плотины в Кажимском водохранилище в 2011-2012 гг., вызвало в последующие годы увеличение значений по ряду показателей (цветность, минерализация, концентрация растворенных веществ и биогенных элементов). Известно (Морозова и др., 2001) негативное влияние затопленного торфа на формирование гидрохимического режима водоемов, когда в результате переработки берегов и разложения растительности в водоем поступают болотные воды, усиливая процессы окисления в воде.

В исследованных нами малых водохранилищах установлено высокое видовое богатство флоры и фауны: 340 видов водорослей, 119 видов макрофитов, 110 видов и форм зоопланктона и 22 систематические группы зообентоса. Состав доминирующих видов фито- и зоопланктона, доминирующих групп зообентоса, а также состав флоры был обычным для региона исследований (Патова, 2007; Тетерюк, 2011, 2012; Батурина и др., 2016). 
Общность происхождения обусловливает наличие сходных черт в развитии водохранилищ различных природных зон. Гидробиологические наблюдения, проведенные на большинстве крупных водоемов такого типа в России, позволили выявить основные закономерности и этапы формирования в них биоты (Куйбышевское водохранилище, 1983; Ривьер, Баканов, 1984; Кудерский, 1986; Современное состояние..., 2002; Дзюбан и др., 2007; Алексевнина, Преснова, 2008; Ермолаева, 2008; Кабушева, 2011; Кузнецова, 2011; Халиулина, Яковлев, 2015; Соловьева, 2016; Яныгина, 2016). Первый этап - становление - характеризуется ростом численности и биомассы фито- и зоопланктона, доминированием в зоопланктоне хищных видов, в бентосе - ростом общей численности и биомассы за счет развития личинок Chironomidae, во флоре - формированием растительных группировок воздушно-водных растений. На этапе стабилизации снижается общее обилие беспозвоночных, в дальнейшем численность и биомасса медленно увеличиваются по мере достижения устойчивого баланса продукционнодеструкционных процессов в новой экосистеме к следующему этапу - «зрелости» водоема. Весь период сопровождается снижением видового разнообразия реофильных видов среди беспозвоночных; в фитопланктоне биомасса формируется за счет диатомовых водорослей при значительном развитии синезеленых; в бентосе олигохеты и моллюски частично замещают хирономид в доминирующем комплексе; в составе флоры в прибрежных зонах развивается воздушно-водная растительность и разрастаются погружённые гидрофиты, на мелководьях может наблюдаться развитие сплавин и заболачивание. Наступление равновесного состояния в крупных водохранилищах происходит через 7-10 (Ермолаева, 2008; Кузнецова, 2011) до 20 лет. В северных водоемах этот процесс более длительный (Ермолаева, 2008; Шевелева, Воробьева, 2009).

Выявленные нами общие черты, характеризующие исследованные малые водоемы на той или иной стадии развития экосистемы, соответствовали уже известным ранее. Так, рост численности и биомассы: в зоопланктоне с доминированием хищных форм, в зообентосе - личинок хирономид, в фитопланктоне желтозеленых и синезеленых водорослей, что вызвало «цветение» воды; в растительном покрове - снижение обилия и сокращение площади сообществ погружённой растительности - черты, характерные для этапа становления.

Доминирование в зоопланктоне малых водохранилищ мирных видов, значительная роль моллюсков и олигохет и, в меньшей степени, личинок хирономид, в количественных показателях развития бентоса при разнообразии других групп донных беспозвоночных, большое значение диатомовых в биомассе фитопланктона, ведущая роль в зарастании водоема настоящей водной растительности (погруженные укореняющиеся гидрофиты и гидрофиты с плавающими листьями) - все это соответствует стадии стабилизации, а учитывая время существования Кажимского водохранилища, вероятно, и стадии «зрелости» водоема.

Вместе с тем наши исследования выявили различный отклик экосистем водохранилищ на антропогенное влияние. Негативное воздействие на сообщества оказали проведенные на Нючпасском водохранилище дноуглубительные работы, одним из результатов которых стало снижение в нижнем пруду численности и биомассы зоопланктона, в основном за счет выпадения из его состава литоральных сообществ, и зообентоса, при доминировании личинок хирономид. Ремонтные работы на плотине Кажимского водохранилища, 
в результате которых уровенный режим был спущен до минимальных значений, привели к осушению части литоральной зоны, что также определило в последующие годы изменения в количественных характеристиках биоты. После того, как водохранилище было наполнено вновь до нормального подпорного уровня, в водоеме отмечали рост численности и биомассы зоопланктона, в основном за счет коловраток. Значительное увеличение цветности воды и содержания основных биогенных элементов привели к массовому развитию в фитопланктоне диатомовых, желто-зеленых и синезеленых водорослей, что вызвало «цветение» воды. В составе фитопланктона также в этот период было отмечено развитие рафидофитовой водоросли G. semen (указан впервые для Республики Коми), вспышки численности которой обычно и стимулируются эвтрофированием водоемов (Korneva, 2014).

Одной из особенностей малых водохранилищ, в том числе исследованных нами, является наличие обширных мелководных участков, небольшая глубина и, как следствие, хорошая прогреваемость. Из-за ветрового перемешивания здесь наблюдается «импульсное» поступление основных биогенных элементов из седиментов (Малая гидроэнергетика, 1989; Ducobu et al., 1998; Гладышев и др., 2004; Дзюбан и др., 2007; Лазарева, 2010; Халиулина, Яковлев, 2015), что и является одной из главных причин «цветения» воды в исследованных нами водохранилищах в летние месяцы. Эта особенность также благоприятствует развитию водной флоры в исследованных водоемах - площадь зарастания составляет от 10 до $40 \%$. Известно (Дамрин и др., 2003; Лихачева, 2007; Кабушева, 2011; Lyashenko, 2013), что зарастание акватории водоема, с одной стороны, происходит в водохранилищах по законам естественного зарастания, с другой - имеет специфические осо- бенности, связанные с переменным режимом уровня воды. В исследованных малых водохранилищах значительную роль в зарастании играет настоящая водная растительность (погруженные укореняющиеся гидрофиты и гидрофиты с плавающими на воде листьями), а состав флоры водохранилищ Вычегодского бассейна обнаруживает большее сходство с озёрной флорой (Тетерюк, 2011, 2012).

Активное развитие зарослей прибрежной водной растительности, особенно в Кажимском и Нювчимском водохранилищах, а также влияние устьевых зон впадающих в них рек обеспечивают большее число таксономических групп и более высокие показатели количественного развития беспозвоночных со стороны заливов, чем в открытой акватории и приплотинной части. К зарастающим участкам приурочены и нагульные участки фитофильных видов рыб, населяющих исследованные водохранилища (Рафиков и др., 2015).

В двух из трех исследованных водохранилищах функционируют садковые рыбные хозяйства. Учитывая двойственную природу водохранилищ, последствия от функционирования садков в этих водоемах можно учитывать и как фактор формирования их биоты, и как элемент современного состояния экосистем. Известно (Стерлигова и др., 2011), что за счет остатков кормов и продуктов метаболизма рыб в водоёмах ускоряются процессы эвтрофирования. В Кажимском водохранилище в месте расположения садков были зафиксированы максимальные показатели развития фитопланктона: при этом на участках вблизи садков увеличение численности происходило за счет истинно планктонных водорослей, на остальных станциях - за счет литоральноэпифитных и эпифитных диатомей. У садков отмечались и наибольшие показатели индекса сапробности. Ранее (Батурина и др., 2015) 
на примере сообществ донных и планктонных беспозвоночных Нювчимского водохранилища были получены сходные результаты. Важно отметить факт массового распространения (особенно в Нювчимском водохранилище) масштабных зарослей элодеи канадской (E. canadensis) и рогоза широколистного (T. latifoliae), указывающих на существующее антропогенное воздействие.

\section{Заключение}

В исследованных нами малых водохранилищах среднетаежной подзоны установлено 340 видов водорослей, 119 видов макрофитов, 110 видов и форм зоопланктона и 22 систематические группы зообентоса. Водоросли фитопланктона были представлены в основном $\beta$ - или $\alpha$-мезосапробными видами, среди них доминировали по обилию диатомовые и цианопрокариоты. В формировании растительного покрова водохранилищ наиболее значимую роль играли водные виды. По составу первой тройки лидирующих семейств (Суреraceae, Potamogetonaceae и Poaceae) таксономическая структура водохранилищной флоры близка к озёрной флоре региона. Состав зоопланктона был обычным для водоемов среднетаежной зоны, доминировали в нем преимущественно Rotatoria и Cladocera. В зообентосе по численности и биомассе преобладали Oligochaeta, Mollusca и Chironomidae.

Трофический статус по биомассе зообентоса и зоопланктона оценивается как олиго- трофный в Нючпасском, как $\alpha$-мезотрофный в Кажимском и от олиго- до $\beta$-мезотрофного в Нювчимском водохранилищах.

Выявленные этапы формирования экосистемы исследованных малых водохранилищ были сходны с таковыми в крупных искусственных водоемах. В период становления экосистемы происходит увеличение количественных показателей развития планктона и бентоса: в зоопланктоне в основном за счет хищных Rotatoria, в фитопланктоне - диатомовых и синезеленых, в макробентосе - личинок Chironomidae. При переходе к стабильному состоянию возрастает численность и биомасса зоопланктона за счет мирных эвпланктонных и литорально-фитофильных видов; в зообентосе по численности и биомассе преобладают Oligochaeta, Mollusca и Chironomidae; в зарастании водоема ведущая роль принадлежит настоящей водной растительности.

Распределение растений и животных по акватории водоемов подчиняется общим закономерностям - различия в степени зарастания и структуре сообществ макрофитов «верхних» и «приплотинных» участков определяют количественные показатели развития и состав зоопланктона и зообентоса.

На современное состояние исследованных водоемов влияют садковые хозяйства, на что указывает изменение структуры и количественных показателей развития фито- и зоопланктона, зообентоса и макрофитов.

Работа выполнена в рамках государственного задания по теме «Животный мир Европейского Северо-Востока России в условиях хозяйственного освоения и изменения окружающей среды» № zос. регистрации 115012860088; при поддержке Комплексной программы УрО РАН по теме «Особенности структурной организации водных экосистем таёжной зоны Европейского Северо-Востока России, сформированных в условиях разных ландшафтов и экологических факторов» № 15-12-4-43, № гос. регистрации 115110610165. 


\section{Список литературы}

Авакян А.Б., Салтанкин В.П., Шарапов В.А. (1987) Водохранилищяа. М., Мысль, 325 с. [Avakjan A.B., Saltankin V.P., Sharapov V.A. Water reservoirs. Moscow, Mysl', 325 p. (in Russian)]

Алексевнина М.С., Преснова Е.В. (2008) Изменение донных сообществ Воткинского водохранилища за время его существования (1962-2006 гг.). Современное состояние водных биоресурсов: Матер. междунар. конф. Новосибирск, с. 272-273 [Alexevnina M.S., Presnova E.V. (2008) Changes of benthic communities in Votkinsk reservoir at the time of its existence (19622006). Modern condition of water biological resources: Mater. Intern. Conf. Novosibirsk, p. 272273 (in Russian)]

Атлас почв Республики Коми (2010) Добровольский Г.В., Таскаев А.И., Забоева И.В. (ред.) Сыктывкар, Коми республиканская типография, 356 с. [Soil Atlas of the Komi Republic (2010) Dobrovol'skij G.V., Taskaev A.I., Zaboeva I.V. (eds.) Syktyvkar, Komi republican printing house, 356 p. (in Russian)]

Балушкина Е.В., Винберг Г.Г. (1979) Зависимость между длиной и массой тела планктонных ракообразных. Экспериментальные и полевые исследования биологических основ продуктивности озер. Винберг Г.Г. (ред.) Л., Зоол. ин-т, с. 58-79 [Balushkina E.V., Vinberg G.G. (1979) Dependence between length and body weight of planktonic Crustacea. The experimental and field research of biological bases of lakes productivity. Vinberg G.G. (ed.) Leningrad, Zoological Institute of the Russian Academy of Sciences, p. 58-79 (in Russian)]

Баринова С.С., Медведева Л.А., Анисимова О.В. (2006) Биоразнообразие водорослей - индикаторов окружающей среды. Tel-Aviv, Pilies Studio, 498 c. [Barinova S.S., Medvedeva L.A., Anisimova O.V. (2006) Diversity of algae indicators in environmental assessment. Tel Aviv, Pilies Studio, 498 p. (in Russian)]

Батурина М.А., Кононова О.Н., Рафиков Р.Р. (2015) Состояние сообществ водных беспозвоночных (планктон, бентос) в условиях эксплуатации в водоёме форелевого хозяйства. Teоретическая и прикладная экология, 4: 84-89 [Baturina M.A., Kononova O.N., Rafikov R.R. (2015) The state of communities of aquatic invertebrates (plankton, benthos) in the conditions in the cage salmon farm. Theoretical and Applied Ecology [Teoreticheskaja i prikladnaja ekologija], 4: 84-89 (in Russian)]

Батурина М.А., Кононова О.Н., Фефилова Е.Б., Хохлова Л.Г., Зиновьева А.Н. (2016) Изученность водных беспозвоночных крупных рек Республики Коми (Печора и Вычегда). Известия Коми научного центра УрО РАН, 3: $42-53$ [Baturina M.A., Kononova O.N., Fefilova E.B., Hohlova L.G., Zinov'eva A.N. (2016) Level of study of aquatic invertebrates of the Komi Republic large rivers (Pechora and Vychegda). Izvestija of the Komi Science Centre of the Ural Division RAS [Izvestija Komi nauchnogo centra UrO RAN], 3: 42-53 (in Russian)]

Биологическое обоснование использования водных объектов Республики Коми для организации товарного рыбоводства. Практические рекомендации (2012) Захаров А.Б. (ред.) Сыктывкар, Коми НЦ УрО РАН, 44 с. [Biological rationale of use of water objects of the Komi Republic for the organization of commodity fish breeding. Practical recommendations (2012) A.B. Zaharov (ed.) Syktyvkar, Komi SC UB RAS, 44 p. (in Russian)]

Власова Т.А. (1988) Гидрохимия главных рек Коми АССР. Сыктывкар, Акад. наук СССР, Урал. отд-ние Коми науч. центр, 152 с. [Vlasova T.A. (1988) Hydrochemistry of the main rivers 
of the Komi. Syktyvkar, Institute of Biology of the Komi Science Centre of the Ural Division of the Akademy of Sciences of the USSR, 152 p. (in Russian)]

Гладышев М.И., Кравчук Е.С., Колмаков В.И., Трусова М.Ю., Иванова Е.А., Грибовская И.В., Сущик Н.Н. Экспериментальное изучение влияния химического состава воды и донных отложений двух небольших водоемов на развитие синезеленых водорослей. Биология внутренних вод, 2: 47-52 [Gladyshev M.I., Kravchuk E.S., Kolmakov V.I., Trusova M.Yu., Ivanova E.A., Gribovskaya I.V., Suschik N.N. (2004) A comparative study of the effect of chemical composition of water and bottom sediments on blue-green algae development in two small waterbodies. Inland Water Biology [Biologija vnutrennih vod], 2: 47-52 (in Russian)]

Гольд 3.Г., Дубовская О.Н., Лужбин О.В. (1996) Состояние экосистемы глубоководного Красноярского водохранилища (1992-1994 гг.). Красноярск, Изд-во Краснояр. гос. ун-та, 39 с. [Gol'd Z.G., Dubovskaja O.N., Luzhbin O.V. (1996) Condition of an ecosystem of the deep-water Krasnoyarsk reservoir (1992-1994). Krasnoyarsk, Krasnoyarsk State University, 39 p. (in Russian)]

Дамрин А.Г., Соловьёва В.В., Плаксина Т.И., Чибилёв А.А., Петрищев В.П. (2003) Ландшафтно-геоботанические особенности формирования геосистем малых водохранилищ (на примере Поляковского водохранилища). Поволжский экологический журнал, 2: 109-118 [Damrin A.G., Solov'jova V.V., Plaksina T.I., Chibiljov A.A., Petrishhev V.P. (2003) Landscape and geobotanic features of geosystem formation in small reservoirs (with the Polyakov Reservoir as an example). Povolzhskiy Journal of Ecology [Povolzhskij ekologicheskij zhurnal], 2: 109-118 (in Russian)]

Двинских С.А., Китаев А.Б. (2014) Особенности функционирования водохранилища как природно-техногенного объекта. Географический вестник, 2: 34-41 [Dvinskih S.A., Kitaev A.B. (2014) Feature functioning reservoir as natural-technogenous object. Geographical Bulletin [Geograficheskij vestnik], 2: 34-41 (in Russian)]

Дзюбан А.Н., Косолапов Д.Б., Корнева Л.Г., Столбунова В.Н. (2007) Комплексная оценка экологического состояния мелководий Рыбинского и Горьковского водохранилищ. Биология внутренних вод, 4: 3-8 [Dzyuban A.N., Kosolapov D.B., Korneva L.G., Stolbunova V.N. (2007) Complex assessment of an ecological status of the littoral zones in the Rybinsk and Gorkiy Reservoirs. Inland Water Biology [Biologija vnutrennih vod], 4: 3-8 (in Russian)]

ЕрмолаеваН.И.(2008) Водные экосистемы. Особенности формирования зоопланктона водохранилищ. Экология. Серия аналитических обзоров мировой литературы, 88 : 69 [Ermolaeva N.I. (2008) Water ecosystems. Features of formation of zooplankton of reservoirs. Ecology. Series of stateof-the-art reviews of the world literature [Ekologija. Serija analiticheskih obzorov mirovoj literatury], 88: 69 (in Russian)]

Кабушева Т.С. (2011) Современное состояние растительности Осиповичского водохранилища. Вестник БГУ, 2 (1): 99-102 [Kabusheva T.S. (2011) The current state of vegetation of the Osipovichsky reservoir. Vestnik BSU [Vestnik BGU], 2 (1): 99-102 (in Russian)]

Кадастр особо охраняемых природных территорий Республики Коми (2014) Дёгтева С.В., Пономарев В.И. (ред.) Сыктывкар, Ин-т биологии Коми НЦ УрО РАН, 428 с. [Cadastre of the especially protected natural territories of the Komi Republic (2014) Djogteva S.V., Ponomarev V.I. (eds.) Syktyvkar, Institute of Biology of the Komi Science Centre of the Ural Division RAS, 428 p. (in Russian)] 
Катанская B.M. (1981) Высшая водная растительность континентальных водоёмов СССР. Методы изучения. Л., Наука, 187 с. [Katanskaja V.M. (1981) The higher aquatic vegetation of continental water bodies of the USSR. Studying methods. Leningrad, Nauka, 187 p. (in Russian)]

Киселев И.А. (1969) Планктон морей и континентальных водоемов. Т. 1. Вводные и общие вопросы планктологии. Л., Наука, 658 с. [Kiselev I.A. (1969) Plankton of the seas and continental water bodies. Vol. 1. Introduction and common questions of the planktology. Leningrad, Nauka, 658 p. (in Russian)]

Китаев С.П. (2007) Основы лимнологии для гидробиологов и ихтиологов. Петрозаводск, Карельский научный центр РАН, 395 с. [Kitaev S.P. (2007) Limnology bases for hydrobiologists and ichthyologists. Petrozavodsk, KarRC of RAS, 395 p. (in Russian)]

Кузнецова О.А. (2011) Сукцессионные изменения донных сообществ глубоководного Красноярского водохранилища. Вестник КрасГАУ, 9: 99-103 [Kuznecova O.A. (2011) Succession changes of bottom communities of the deep-water Krasnoyarsk reservoir. Vestnik of the Krasnoyarsk State Agrarian University [Vestnik KrasGAU], 9: 99-103 (in Russian)]

Кудерский Л.А. (1986) Экология и биологическая продуктивность водохраниилищ. М., Знание, 64 с. [Kuderskij L.A. (1986) Ecology and biological efficiency of reservoirs. Moscow, Znanie, 64 p. (in Russian)]

Куйбышевское водохранилище (1983) Монаков А.В. (ред.) Л., Наука, 213 с. [Kuibyshev reservoir (1983) Monakov A.V. (ed.) Leningrad, Nauka, 213 p. (in Russian)]

Лазарева В.И. (2010) Структура и динамика зоопланктона Рыбинского водохранилища. M., КМК, 183 c. [Lazareva V.I. (2010) Structure and dynamics of zooplankton of the Rybinsk reservoir. Moscow, KMK, 183 p. (in Russian)]

Лихачева Т.В. (2007) Оценка стадии сукцессии растительности водохранилищ Удмуртии. Известия Челябинского научного иентра, 3: 54-59 [Lihacheva T.V. (2007) The estimation of stage of the vegetation succession of reservoirs of Udmurtia. Izvestija of the Chelyabinsk Scientific Center [Izvestija Cheljabinskogo nauchnogo centra], 3: 54-59 (in Russian)]

Малая гидроэнергетика (1989) Михайлов Л.П. (ред.) М., Энергоатом-издат, 240 с. [Small power hydroengineering (1989) Mihajlov L.P. (ed.) Moscow, Energoatom-izdat, 240 p. (in Russian)]

Методика изучения биогеоценозов внутренних водоемов (1975) Мордухай-Болтовской Ф.Д. (ред.) М., Наука, 240 с. [Technique of studying of biogeocenoses of inland water bodies (1975) Morduhaj-Boltovskoj F.D. (ed.) Moscow, Nauka, 240 p. (in Russian)]

Морозова О.Г., Пен Р.3., Репях С.М. (2001) Влияние затопленных растительных остатков на формирование гидрохимического режима водоема-охладителя Березовской ГРЭС-1. 2. Выделение факторов формирования качества воды. Химия растительного сырья, 1: 8387 [Morozova O.G., Pen R.Z., Repjah S.M. (2001) Influence of the flooded vegetable oddments on formation of the hydrochemical mode of a reservoir-cooler of Beryozovskaya GRES -1.2. Selection of factors of formation of quality of water. Chemistry of vegetable raw materials [Himija rastitel'nogo syr'ja], 1: 83-87 (in Russian)]

Оксиюк О.П., Стольберг Ф.В. (1986) Управление качеством воды в каналах. Киев, Наукова думка, 176 с. [Oksijuk O.P., Stol'berg F.V. (1986) Quality management of water in channels. Kiev, Naukova dumka, 176 p. (in Russian)]

$$
-443-
$$


Оксиюк О.П., Жукинский В.Н., Брагинский Л.П. (1993) Комплексная экологическая классификация качества поверхностных вод суши. Гидробиологический журнал, 29 (4): 62-76 [Oksijuk O.P., Zhukinskij V.N., Braginskij L.P. (1993) Complex ecological classification of quality of the inland water. Hydrobiological journal [Gidrobiologicheskij zhurnal], 29 (4): $62-76$ (in Russian)]

Определитель зоопланктона и зообентоса пресных вод Европейской России. Т. 1: Зоопланктон (2010) Алексеев В.Р., Цалолихин С.Я. (ред.) М., КМК, 495 с. [Identification guide of zooplankton and zoobenthos of fresh water bodies of the European Russia. Vol. 1: Zooplankton (2010) Alekseev V.R., Calolihin S.Ja. (eds.) Moscow, KMK, 495 p. (in Russian)]

Патова Е.Н. (2007) Цианопрокариотическое “цветение” водоемов восточно-европейских тундр (флористические и функциональные аспекты). Теоретическая и прикладная экология, 3: 4-10 [Patova E.N. (2007) Cyanoprokaryotic «bloom» of ponds in East-European tundra (floristic and functional aspects). Theoretical and Applied Ecology [Teoreticheskaja i prikladnaja jekologija], 3: 4-10 (in Russian)]

Протасов А.А. (2011) Жизнь в гидросфере. Очерки по общей гидробиологии. Киев, Академпериодика, 704 с. [Protasov A.A. (2011) Life in the hydrosphere. Essays on the common hydrobiology. Kiev, Akademperiodika, 704 p. (in Russian)]

Рафиков Р.Р., Захаров А.Б., Новоселов А.П. (2015) Формирование рыбного населения малых водохранилищ Республики Коми. Вестник Северного (Арктического) федерального университета. Серия: Естественные науки, 3: 59-67 [Rafikov R.R., Zaharov A.B., Novoselov A.P. (2015) Formation of ichtiophauna in the minor reservoirs of the Komi Republic. Vestnik of Northern (Arctic) Federal University. Series: Natural Sciences [Vestnik Severnogo (Arkticheskogo) federal'nogo universiteta. Serija: Estestvennye nauki], 3: 59-67 (in Russian)]

Ривьер И.К., Баканов А.И. (1984) Кормовая база рыб. Биологические ресурсы водохранилищ. Буторин Н.В., Поддубный А.Г. (ред.) М., Наука, с. 100-132 [Riv'er I.K., Bakanov A.I. (1984) Food supply of fishes. Biological resources of reservoirs. Butorin N.V., Poddubnyj A.G. (eds.) Moscow, Nauka, p. 100-132 (in Russian)]

Руководство по методам гидробиологического анализа поверхностных вод и донных отложений (1983) Абакумов В.А. (ред.) Л., Гидрометеоиздат, 239 с. [Guide to methods of the hydrobiological analysis of the surface water and ground deposits (1983) Abakumov V.A. (ed.) Leningrad, Gidrometeoizdat, 239 p. (in Russian)]

Современное состояние экосистемы Шекснинского водохранилища (2002) Литвинов А.С. (ред.) Ярославль, Издательство ЯГТУ, 368 с. [Modern state of the Sheksna Reservoir ecosystem (2002) Litvinov A.S. (ed.) Yaroslavl, Yaroslavl state technical university, 368 p. (in Russian)]

Соловьева В.В. (2016) Этапы эволюции природы малых водохранилищ Среднего Поволжья. Архивариус, 3: 20-24 [Solov'eva V.V. (2016) Stages of evolution of the nature of small reservoirs of the middle Volga region. Archivist [Arhivarius], 3: 20-24 (in Russian)]

Стерлигова О.П., Китаев С.П., Ильмаст Н.В., Комулайнен С.Ф., Кучко Я.А., Павловский С.А., Савосин Е.С. (2011) Состояние заливов Онежского озера при товарном выращивании радужной форели. Поволжский экологический журнал, 3: 386-393 [Sterligova O.P., Kitaev S.P., Il'mast N.V., Komulajnen S.F., Kuchko Ja.A., Pavlovskij S.A., Savosin E.S. (2011) Status of Onega lake bays affected by commercial rainbow trout cultivation. Povolzhskiy Journal of Ecology [Povolzhskij ekologicheskij zhurnal], 3: 386-393 (in Russian)] 
Тетерюк Б.Ю. (2011) Водная и прибрежно-водная растительность озера Ямозеро (Республика Коми). Растительность России, 19: 101-116 [Teteryuk B.Yu. (2011) Aquatic and helophytic vegetation of the Yamozero Lake (The Komi Republic). Vegetation of Russia [Rastitel'nost' Rossii], 19: 101-116 (in Russian)]

Тетерюк Б.Ю. (2012) Флора древних озёр Европейского Северо-Востока России. Известия Самарского научного центтра РАH, 14 (1): 82-90 [Teteryuk B.Yu. (2012) Flora of the ancient lakes of European North-East of Russia. Izvestija of the Samara Scientific Center RAS [Izvestija Samarskogo nauchnogo centra RAN], 14 (1): 82-90 (in Russian)]

Халиулина Л.Ю., Яковлев В.А. (2015) Фитопланктон мелководий в верховьях Куйбышевского водохранилища. Казань, Изд-во Академии наук PT, 171 с. [Khaliullina L.Yu., Yakovlev V.A. (2015) Phytoplankton of shoals in upper reaches of the Kuibyshev reservoir. Kazan, Academy of Sciences of the Republic of Tatarstan, 171 p. (in Russian)]

Харитонов В.Г. (2014) Диатомовые водоросли Колымы. Магадан, Кордис, 496 с. [Kharitonov V.G. (2014) Diatoms of the Kolyma. Magadan, Kordis, 496 p. (in Russian)]

Шевелева Н.Г., Воробьева С.С. (2009) Состояние и развитие фито- и зоопланктона нижнего участка Ангары, прогноз формирования планктона в Богучанском водохранилище. Журнал Сибирского федерального университета. Биология, 2 (3): 313-326 [Sheveleva N.G., Vorob'eva S.S. (2009) State and development of phyto- and zooplankton in lower reach of the Angara river: prognosis for forming plankton in Boguchanskoe reservoir. Journal of Siberian Federal University. Biology [Zhurnal Sibirskogo federal'nogo universiteta. Biologiya], 2(3): 313-326 (in Russian)]

Яныгина Л.В. (2016) Особенности многолетней динамики зообентоса на зарегулированном участке реки Оби. Журнал Сибирского федерального университета. Биология, 9 (4): 427-440 [Yanygina L.V. (2016) Features of zoobenthos long-term dynamics in regulated area of $\mathrm{Ob}$ river. Journal of Siberian Federal University. Biology [Zhurnal Sibirskogo federal'nogo universiteta. Biologiya], 9 (4): 427-440 (in Russian)]

Ciblis Martina L., Principe R., Gari N. (2013) Effect on a dam on epilithic algal communities of a mountain stream: before-after dam constraction comparison. Journal of Limnology, 72 (1): 79-94

Ducobu H., Huisman J., Jonker R.J., Mur L.R. (1998) Competition between a prochlorophyte and a cyanobacterium under various phosphorus regimes: comparison with the Droop model. Journal of Phycology, 34: 467-476

Guiry M.D., Guiry G.M. (2016) AlgaeBase. World-wide electronic publication, National University of Ireland, Galway. http://www.algaebase.org; searched on 11 November 2016

Ejsmont-Karabin J. (1998) Empirical equations for biomass calculation of planktonic rotifers. Polish Archives of Hydrobiology, 45: 513-522

Korneva L.G. (2014) Invasions of alien species of planktonic microalgae into the fresh waters of Holarctic (review). Russian Journal of Biological Invasions, 5(2): 65-81

Krammer K., Lange-Bertalot H. (1991) Bacillariophyceae. Teil 3. Centrales, Fragilariaceae, Eunotiaceae. Süßwasserflora von Mitteleuropa. Bd. 2/3. Stuttgart, Jena, 576 p.

Lyashenko G.F. (2013) Dynamics of hydrophilic phytocenoses in the littoral of the Rybinsk Reservoir. Inland Water Biology, 6 (1): 26-31

Sládeček V. (1973) System of water quality from the biological point of view. Archiv fur Hydrobiologie, 7(7): 1-218

$$
-445-
$$

